\title{
The Development of Smart Snake and Ladder Media in Mastery of English Vocabulary Grade III at SDI Babussalam Pandean Durenan Trenggalek
}

\author{
Uswatun Kasanah ${ }^{1 凶}$, Muhamad Zaini ${ }^{2}$, Nur Efendi ${ }^{3}$, Adi Wijayanto ${ }^{4}$, Eni Setyowati ${ }^{5}$ \\ 12345 State Islamic University of Sayyid Ali RahmatullahTulungagung, Jawa Timur, Indonesia \\ 凶 email: uswatunkasanah1905@gmail.com
}

\begin{abstract}
Received:
24 January 2022

Revised:

02 February

2022

Accepted:

02 February

2022

Published:

05 February

2022

ABSTRACT

The monotonous learning media in English vocabulary, and memorizing method make students bored, so needed media innovations for these lessons, such as Smart Snake and Ladder. This paper aims to develop learning media Smart Snake and Ladder in mastering English vocabulary. The type of research used is $R \& D$. The results of this research and development, showed that: (1) The development of the Smart Snake and Ladder media product pays attention to the safe appearance, and modified ways of playing to attract the user's attention, curiosity, and describe the theme material for elementary school children. (2) The development of smart snake and ladder media is very valid and feasible to use to improve English vocabulary mastery, as the validation results from material experts I get a $100 \%$ validity level and material II experts get $92.5 \%$, media experts I $81.25 \%$, media experts II $85 \%$, and media experts III $84.37 \%$. (3). The effectiveness of using smart snake and ladder media can be seen from the pre-test and post-test data. The average value of the pre-test is 81.87 while the average value of the post-test is 96.20. Apart from the pre-test and post-test data, it can also be seen from the student assessment data with an average score of 99.9\%.
\end{abstract}

Keywords: Development Media; Islamic Elementary School; Smart Snake and Ladder; Vocabulary

\section{INTRODUCTION}

The government has implemented improvements to improve the quality of education at various types and levels. However, the facts on the ground have not shown satisfactory results. This condition can be seen in the quality of education in Indonesia today. Improving and developing the quality of education is a problem that demands attention, so it is necessary to improve the curriculum. Curriculum improvement is a common thing to improve the quality of a country's education. Likewise, to improve the quality of national education, one way to do that can be done by evaluating and updating the national education curriculum. Reforming a curriculum aims to make students smart, moral, creative, communicative, and tolerant in religious life. In the educational process, especially education in schools, actually not only curriculum improvement, but learning is the most basic activity. 
The success of achieving educational goals is determined by the learning experienced by students. In learning, the use of various media and learning resources must also be considered. Fun learning methods can also motivate students to understand learning. Discussion is a way of delivering learning by providing opportunities for students to discuss, analyze to gather opinions, share information to make conclusions in solving problems. Thus the teacher can find out the success in the learning of their students or find out which of the students have succeeded and who still need help.

Learning media are all tools or intermediaries in any form that can be used to convey material in the learning process. Learning media include people, materials, equipment, or activities that create conditions that enable students to acquire knowledge, skills, and attitudes. The selection of appropriate learning media will provide great benefits for educators and students.

In general, the benefits that can be obtained are that the learning process is more interesting, more interactive, the quality of student learning can be improved and the teaching and learning process can be done anywhere and anytime. easy to understand and can eliminate verbalism. The development of the era which continues to progress in various fields and elements of life, makes the government must continue to improve the existing education system. This era of globalization requires students and all elements of society to be able to read the times and be able to compete with other countries.

One of the important elements to be able to interact with other countries is the problem of language. The language that must be mastered by everyone to interact with foreigners. The international language is English, by mastering English we can keep up with technological developments and developments in other countries that allow us to make improvements in our country. The Indonesian government, in this case, the Ministry of National Education, has introduced English at the elementary school (SD) level in almost all rural areas in Indonesia.

Recently, learning English at the elementary level has attracted the attention of experts in the field of language and language learning, especially English in Indonesia. One of the reasons the Indonesian government introduces English to elementary school children is based on the fact that English is used in every aspect of people's lives. This is due to the rapid advancement of information technology.

The development of the era which continues to progress in various fields and elements of life, makes the government must continue to improve the existing education system. This era of globalization requires students and all elements of society to be able to read the times and be able to compete with other countries. One of the important elements to be able to interact with other countries is the problem of language. The language that must be mastered by everyone to interact with foreigners. The international language is English, by mastering English we can keep up with technological developments and developments in other countries that allow us to make improvements in our country.

The researcher's observation on students at SDI Babussalam Pandean Durenan Trenggalek school is that students think that English is a difficult subject matter. English is included in a foreign language which is currently a demand of the times in which 
various aspects of life are often encountered, but due to the lack of enthusiasm of students in learning foreign languages, it makes they are lazy to study. As for English subjects, students are required to always memorize various vocabulary in English.

Mastery of English vocabulary itself is very necessary for the process of learning English because the core of language learning is mastering the language itself (Apriyanto \& Anum, 2018; Triana et al., 2020). Knowing the language begins with learning the various vocabulary of the language being studied. Of course, by training students to master English vocabulary. Because without practice, skills in memorizing will be less than students who often memorize vocabulary.

The provision of vocabulary material is generally limited to the teacher reading then the students imitate, usually done repeatedly so that students memorize it. Here requires high concentration so that students can memorize the vocabulary that has been read by the teacher. Less focused students will have difficulty and feel that learning English is a difficult subject. Learning packaging that attracts students' interest in learning is very necessary for the application of learning English. Giving vocabulary in English must also be able to attract the attention of students so that students can remember a fun way of learning.

Abdul Majid suggests that learning resources are defined as information presented in various media that can help students in the learning process as a form of embodiment of the curriculum. The form is not limited either in the form of print, video, software format, or a combination of various other formats. However, the objective of learning resources is to help students understand a learning material. Therefore, students must be able to learn independently in finding learning resources that are by the material to be studied.

From the discussion above, he is a new researcher by conducting research and development of English language vocabulary Smart Snake and Ladder media for third grade MI/SD students, in this case, the researcher conducted research that took place at SDI Babussalam Durenan which had never been held before. research with the same title. Researchers also want to know the results of the application of the Smart Snake and Ladder media whether it is also able to provide real changes in the way students think and be able to increase vocabulary in English which is considered quite difficult for most students.

Another advantage of this research is that it was carried out during the Covid-19 pandemic where schools were active in alternating ways and also only studied for 2 hours at school. Not only that, but students must also comply with health protocols in the form of keeping a distance, wearing masks, and washing hands frequently. The students come alternately in one class, each 1 wave consists of 5 students and this consists of 4 waves.

The development of Smart Snake and Ladder media products pays attention to several aspects so that the designed Smart Snake and Ladder media can be used by students in learning. Some of the aspects used in developing the Smart Snake and Ladder media include aspects in the selection of materials that are adapted to the current curriculum, in addition to those that are adjusted to $\mathrm{KI}$ and $\mathrm{KD}$. KI, KD are used as a 
reference in formulating learning indicators so that the Smart Snake and Ladder media developed is by the achievement of learning objectives. The Smart Snake and Ladder media product is designed so that users can easily understand the material presented by learning while playing. The material presented is designed using interesting animated pictures, where later students must mention and write down the vocabulary they occupy in English.

The development of the Smart Snake and Ladder media product by paying attention to the appearance of the snake and ladder board that is safe for students to use to the modified way of playing. The objective of a display in the Smart Snake and Ladder media is to attract the user's attention, attract the user's curiosity so that they play and learn with pleasure. In addition, the Smart Snake and Ladder media display also aim to describe the material contained in the textbook. The design of the Smart Snake and Ladder media development is designed to be as attractive as possible according to the theme of elementary school children.

\section{METHOD}

The research was conducted at SDI Babussalam Pandean Durenan Trenggalek. The research subjects were third grade students. The development of learning media carried out by researchers is by the steps of developing the Borg and Gall model. However, the steps are adjusted to the needs that exist in the field. The use of interactive multimedia learning media in the learning process makes students motivated so that they become more effective and efficient and can improve student learning outcomes. Yusufhadi Miarso argues that learning media are everything that is used to channel messages and can stimulate the thoughts, feelings, attention, and willingness of the learner so that it can encourage a deliberate, objectiveful, and controlled learning process.

The steps taken by the researcher are needs analysis, planning, product description, data analysis of test results, product revision, then producing the final product in the form of Smart Snake and Ladder media. The first step taken by researchers in this study is to determine the location selection This location was chosen because the school has its way of learning during the pandemic. Researchers took English material in this study because there were several obstacles in learning English for grade III at SDI Babussalam Pandean Durenan Trenggalek. One of the obstacles experienced by grade III students is that they are getting bored when learning English using only monotonous learning media. Some of this information was obtained when conducting observations at school and conducting interviews with several third-grade teachers. Observations made by researchers face to face at SDI Babussalam Pandean Durenan Trenggalek.

The second stage, in compiling research and development, also pays attention to the stages that need to be carried out such as paying attention to the goals of the products that have been developed. It is intended that the products that have been developed are effectively used in the learning process both face-to-face. At this stage, 
the researcher collects references according to the product developed, namely the smart snake and ladder media in learning English.

The third stage, the development of a product draft in the form of a smart snake and ladder media, was designed and developed according to the data from the previous information collection. The planning stage is done by determining the elements that are needed in the learning media.

The fourth stage is product validation. Product validation is carried out to determine the level of feasibility of a product being made. Validation is given to media experts and material experts. In this study, media expert validation was carried out on lecturers and teachers, as well as material expert validation. In the fifth stage, the data obtained from the expert validation results are used to revise the product. This process is carried out to reduce product weaknesses that arise from the validation results which are useful for product development before being tested in the field.

The sixth stage, conducting field trials to test products that have been validated by experts. Product trials at this stage were carried out on third-grade students of SDI Babussalam Pandean Durenan Trenggalek. At this stage, the researchers in addition to testing the product also distributed questionnaires given to students and conducted observations and interviews. Trial of smart snake and ladder media products was carried out directly in grade III SDI Babussalam Pandean Durenan Trenggalek, along with the distribution of questionnaires, observations, and interviews were carried out while maintaining the health protocol. The trial was carried out when grade III had an offline (outside the network) / face-to-face class schedule.

The seventh stage, which in this stage, is carried out after analyzing the data from the field test. This stage is carried out to determine the accuracy of the product developed. At this stage, the product developed can be accounted for the level of validity, practicality, and effectiveness. This product revision is carried out if in its application there are still shortcomings and weaknesses.

\section{FINDINGS AND DISCUSSION}

Researchers developed a product in the form of a smart snake and ladder media in improving the mastery of English vocabulary for third-grade students. This smart snake and ladder media is designed as simply as possible without reducing the content of the material. The presentation of the material is also presented based on the basic competencies contained in the learning books used at this time. Based on the results of the assessment provided by media experts and material experts, the smart snake and ladder media is suitable for use in the learning process. However, the researchers also paid attention to the suggestions given by each validator to make improvements to the smart snake and ladder media before the product was tested.

The overall media feasibility test component from each validator obtained an average presentation value of $84 \%$. While the overall material feasibility test from each expert validator gets a percentage value of $99 \%$. This shows that the results of the assessment given by media experts and material experts to the smart snake and ladder media learning media are suitable for use in the learning process. However, the 
researchers also paid attention to the suggestions given by each validator to make improvements to the smart snake and ladder learning media before the product was tested. The results of the overall component test assessment starting from the general aspect, the aspect of presenting the material, and the aspect of presenting the feasibility are included in the category of qualifying for students or users.

The development of smart snake and ladder media has the aim of increasing students' vocabulary mastery in English subjects. This is proven through the results of the pretest and posttest from the students. The results of the pretest show that students only know some of the material. However, judging by the results of the posttest the researchers got different results from the students. With the Smart Snake and Ladder media, students can answer questions properly and correctly according to the material contained in the question.

One of the advantages of the smart snake and ladder media learning media is that students can easily learn independently by using this learning media. Smart snake and ladder learning media can be used when learning in the classroom with a learning system while playing. The application is also very easy because it can be done with a group.

The development of smart snake and ladder learning media is very useful for teachers about the importance of learning in this modern era. The teacher easily explains the material that is supported by a snake and ladder board containing learning materials. This smart snake and ladder media is a medium that is easily understood by students. This is based on one student who said that "this smart snake and ladder learning media makes learning more fun because it is accompanied by games". Based on this statement, it can be concluded that there is a comparison between learning that uses media and learning that does not use media.

\section{Media Validity of Smart Snake and Ladder in Mastering English Vocabulary}

The validity of the Smart Snake and Ladder media in this study was seen from the validation results of product experts, where the score for product validation was $100 \%$ material experts, display media experts were $85 \%$, and learning experts were $100 \%$. The results of obtaining product validation show very valid numbers, so Smart Snake and Ladder media can be used in the learning process. In addition, the results of the questionnaire responses of students to the Smart Snake and Ladder media used were $99 \%$ on the criteria aspect of the Smart Snake and Ladder media, 100\% on the aspect of student involvement in using the Smart Snake and Ladder media, and 99\% on the aspect of interest in learning. The percentage results are in the very successful predicate, meaning that the use of Smart Snake and Ladder media can help users in learning. The use of Smart Snake and Ladder media is considered to be able to help students in learning English vocabulary according to their abilities (see Ayoub et al., 2014; Bassetti \& Cook, 2011; Bohling-philippi et al., 2015; Creswell, 2014; Niklas et al., 2016; Romo, 2015).

Some things about using Smart Snake and Ladder media for students in the learning process are as follows: 
a. Media Smart Snake and Ladder helps students in developing their ability to solve a problem.

b. Media Smart Snake and Ladder helps students in learning. So that they can write down the correct answer.

c. Media Smart Snake and Ladder helps students learn how to find multiple answers to a problem.

d. Media Smart Snake and Ladder helps students in learning interspersed with games.

Adi Wijayanto revealed that the media is a source of learning so that broadly learning media can be interpreted by humans, objects, or events that allow students to gain knowledge and skills. The results of this study are supported by several theories and research that explain the relationship between learning media and the learning outcomes of students. Likewise in learning, the function of the media can help the learning process of students towards their learning outcomes, so that they get maximum results.

The validity of the Smart Snake and Ladder media in this study supports the research conducted by Siti Kholipah Maratun in a study entitled the development of snake ladder media on economics subjects for class X SMA Muhammadiyah 1 the Metro Year 2017/2018, with an average validity result of 4.1 or said worthy. In this study, it can be said that the Smart Snake and Ladder media is suitable for use in learning.

\section{The Effectiveness of Smart Snake And Ladder Media in Mastering English Vocabulary}

Smart Snake and Ladder media is a print media that is very easy to use in learning because it is more concise and easy for students to understand. Media is said to be effective if the media can be used in distributing learning content and can improve a good result. Research and development on the Smart Snake and Ladder media aim to measure how effective the Smart Snake and Ladder media developed in learning is.

Determination of the effectiveness of the Smart Snake and Ladder media in this study can be seen from the results of working on the practice questions contained in the pre-test and post-test. The results of the implementation of the media showed good results. Based on the pre-test and post-test data, the pre-test got an average score of 81.87 and the post-test was 96.20. The results of the average score indicate an increase in students' ability in mastering English vocabulary.

In determining the effectiveness of this study, it supports or is the same as the research conducted by Sudarmika Parmiti Simamora in the thesis entitled Development of innovative snake and ladder media to increase the learning interest of fourth-grade elementary school students. In this study, it turned out that snakes and ladders were also effective in increasing students' interest in learning.

Learning is a process of communication between students, teachers, and teaching materials. Communication will not run without the help of means of delivering messages or media. The media used in learning is called learning media, 
which has a function as an intermediary for messages. At present, the learning process should use various media according to the character of the subject, with the motto of learning from various sources (free), so that the expected competencies are achieved properly. So the media in learning plays an important role in achieving a learning goal. The communication relationship between teachers and students will be better and more efficient if using the media.

Learning media are all tools and materials that can be used for the teaching and learning process. Such as pictures, charts, video cassettes, films, textbooks, television, the internet. Learning media is a tool or form of stimulus that serves to convey learning messages. Stimulus forms can be used as media including human relationships or interactions, reality, moving images or not, writing, and recorded sound. Learning media is also everything that is used to explain the concept of verbal or abstract material to be real so that it can stimulate the thoughts, feelings, concerns, and interests of students who focus on the occurrence of the learning process. Researchers can conclude that the stimulus is used to convey learning. Media can be in the form of humans, real images, or real images. The media is endeavored to stimulate the thoughts, feelings, concerns, and interests of students.

Yusuf Hadi Miarso states that learning media are everything that is used to channel messages and can stimulate the thoughts, feelings, attention, and willingness of the learner so that it can encourage a deliberate, objectiveful, and controlled learning process. Researchers can conclude the opinions of the experts above, it can be concluded that learning media are everything that can be used to convey and distribute messages from sources (educators) in a planned manner to create a conducive learning environment where the recipients (students) can carry out the learning process. learn efficiently and effectively and to increase students' interest in learning. The use of learning media can also create a meaningful learning process so that students can absorb their learning.

The function of learning media has a function and role as described including: a) Capturing an object or certain events important events or rare objects can be immortalized with photos, films or recorded via video or audio, then the event can be saved and can be retrieved. used when necessary, b) manipulating certain circumstances, events, or objects. Through learning media, teachers can present abstract lesson materials in concrete so that they are easy to understand and can eliminate verbalism. In addition, learning media can also help display objects that are too large that cannot be displayed in class. To display these objects the teacher can use slide films, photographs, or pictures, c) To manipulate the situation, learning media can also display a process or movement that is too fast that is difficult to follow, such as car movements, airplane movements, and so on, d) Increase students' enthusiasm and motivation to learn, the use of media can increase students' learning motivation so that students' attention to learning materials can be further increased. For example, before explaining the subject matter about pollution, to attract students' attention to the topic, the teacher first plays a film about flooding or industrial waste and so on. 
Researchers can conclude the opinions of the experts above, namely several functions of learning media, including capturing rare objects that are immortalized through photos, videos, and audio. Manipulating certain circumstances, events, or objects. Helps display large objects into small and small objects into large through slide films. Increase students' enthusiasm for learning. For example, explaining about flooding, from here the media is useful as an intermediary by playing a slide film about flooding.

\section{CONCLUSION}

The results of this research and development, the researchers concluded that: (1) The results of the assessment provided by media experts that the product design for developing smart snake and ladder media was feasible to use with a validity level of media experts I $81.25 \%$, media experts II $85 \%$, media experts III $84.37 \%$ or can be said to be very valid. The development of the Smart Snake and Ladder media product by paying attention to the appearance of the snake and ladder board that is safe for students to use to the modified way of playing. The objective of a display in the Smart Snake and Ladder media is to attract the user's attention, attract the user's curiosity so that they play and learn with pleasure. In addition, the Smart Snake and Ladder media display also aim to describe the material contained in the textbook. The design of the Smart Snake and Ladder media development is designed to be as attractive as possible according to the theme of elementary school children. (2) The development of smart snake and ladder media is very valid and feasible to use to improve English vocabulary mastery. Based on the validation results from material experts. Based on the test results from material experts I got a $100 \%$ validity level and material experts II got $92.5 \%$ meaning it was very valid. (3). The effectiveness of using smart snake and ladder media can be seen from the pre-test and post-test data. The average value of the pre-test is 81.87 while the average value of the post-test is 96.20. Apart from the pre-test and post-test data, it can also be seen from the student assessment data with an average score of $99.9 \%$.

\section{REFERENCES}

Apriyanto, S., \& Anum, A. (2018). Gender Dynamics on Speaking Interaction in the College Classroom. Jurnal Smart, 4(2), 73. https://doi.org/10.26638/js.692.203x Ayoub, C. C., Bartlett, J. D., \& Swartz, M. I. (2014). Parenting and Early Intervention. In Wellbeing (Issue January). https://doi.org/10.1002/9781118539415.wbwell009 Bassetti, B., \& Cook, V. (2011). Language and cognition: The second language user. 1-42. Bohling-philippi, V., Crim, C., Cutter-mackenzie, A., Edwards, C., Desjean-perrotta, B., Finch, K., Brien, L. O., \& Wilson, R. (2015). International Journal of Early Childhood. 3(1), 1-103.

Akbar, Reza Oktiana, and Sipendi Supendi, 'Pengaruh Penerapan Pembelajaran Aktif Tipe Quiz Team Terhadap Prestasi Belajar Matematika Pada Pokok Bahasan Bangun Ruang Sisi Datar (Di SMP Nurul Halim Widasari Kabupaten 
Indramayu)', Eduma: Mathematics Education Learning and Teaching, 1.2 (2012) https://doi.org/10.24235/eduma.v1i2.295

Creswell, J. (2014). Research design: Qualitative, Quantitative, and Mixed Methods Approaches (V. Knight (ed.); Fourth Edi). SAGE Publication. https://doi.org/10.4135/9781849208956

Dr.Wina Sanjaya, M.Pd, 'Perencanaan Dan Desain Sistem Pembelajaran - Dr. Wina Sanjaya, M.Pd - Google Books', Kencana,Prenadamedia Group, 2015

Gerhana, Yana Aditia, Entik Insanudin, Undang Syarifudin, and Mohammad Rizal Zulmi, 'Design of Digital Image Application Using Vigenere Cipher Algorithm', in Proceedings of 2016 4th International Conference on Cyber and IT Service Management, CITSM 2016, 2016 https://doi.org/10.1109/CITSM.2016.7577571

Idi, Abdullah, Pengembangan Kurikulum: Teori \& Praktik, Yogyakarta: Ar-Ruzz, 2010

Kholipah, Siti, Maryatun, and Meyta Pritandhari, 'Pengembangan Media Pembelajaran Ular Tangga Pada Mata Pelajaran Ekonomi Kelas X Sma Muhammadiyah 1 Metro Tahun Pelajaran 2017 / 2018', Edunomia: Jurnal Ilmiah Pendidikan Ekonomi, $1.1(2020)$

Miarso, Yusufhadi, Menyemai Benih Teknologi Pendidikan, Computer, 2007

Mu'arif, Annisa Nurhidayati, Farahdila Damayanti, Retno Akmalia, Tita Arsfenti, and Darmadi Darmadi, 'Pengembangan Kurikulum 2013 Dalam Meningkatkan Pendidikan Karakter Di Sekolah Dasar', EDUKATIF: JURNAL ILMU PENDIDIKAN, 3.1 (2021) https://doi.org/10.31004/edukatif.v3i1.164

Niklas, F., Nguyen, C., Cloney, D. S., Tayler, C., \& Adams, R. (2016). Self-report measures of the home learning environment in large scale research: Measurement properties and associations with key developmental outcomes. Learning Environments Research, 19(2), 181-202. https://doi.org/10.1007/s10984-016-92069

Romo, R. (2015). BUILDING SELF THROUGH FOREIGN LANGUAGE LEARNING : A case study of four adult language learners 'emerging identities. October.

Rusman, 'Manajemen Kurikulum, Bandung.', Program Studi Pengembangan Kurikulum Sekolah Pasca Sarjana Universitas Pendidikan Indonesia., 2008

Sanjaya, Wina, and Wina Sanjaya, 'Strategi Pembelajaran Berorientasi Standar Proses Pendidikan / Wina Sanjaya', 1. MODEL PEMBELAJARAN. BELAJAR DAN MENGAJAR, Strategi Pembelajaran Berorientasi Standar Proses Pendidikan / Wina Sanjaya, 2008.2008 (2008)

Sibuea, Mustika Fitri Larasati, and Hommy Dorthy Ellyany Sinaga, 'Peningkatan Kemampuan Matematika Siswa Sekolah Dasar Melalui Media Pembelajaran Ular Tangga Aljabar', JURNAL MATHEMATIC PAEDAGOGIC, 3.1 (2018) https://doi.org/10.36294/jmp.v3i1.304

Triana, Y., Sari, I. F., \& Apriyanto, S. (2020). Language features and causes of suicide case from forensic linguistics point of view. International Journal of Psychosocial Rehabilitation, $24(6)$, 7955-7966. https://doi.org/10.37200/IJPR/V24I6/PR260803

Utami, I K, and M H Abdulah, 'Pengembangan Media Ular Tangga Dalam 
Pembelajaran Tema Daerah Tempat Tinggalku Peserta Didik Kelas IV Sekolah Dasar', Jurnal Pendidikan Guru Sekolah Dasar, 8.3 (2020)

Wijayanto, Adi, 'Pengaruh Metode Guided Discovery, Dan Metode Movement Exploration Serta Persepsi Kinestetik Terhadap Hasil Belajar Pukulan Atas Bulutangkis Pada Mahasiswa Iain Tulungagung', Halaman Olahraga Nusantara (Jurnal Ilmu Keolahragaan), 1.2 (2018) <https://doi.org/10.31851/hon.v1i2.1976>

Zaini, M, and Retno Jumirah, 'Pengembangan Perangkat Pembelajaran Topik Ekologi Terhadap Keterampilan Berpikir Kritis Siswa Madrasah Aliyah', Jurnal Pendidikan Biologi Indonesia, 2.1 (2016) 